\title{
TEMA: OSTEONECROSIS OF THE MAXILARIES ASSOCIATED WITH USE OF BIPHOSPHONATE
}

\section{AUTORES}

Jamille dos Passos Lacerda

E-mail do autor correspondente: janlacerda.j!@gmail.com

\section{INSTITUIÇÃO AFILIADA}

Departamento de Ciências
Odontológicas - GOE/UNIAVAN-
Macapá, Amapá, Brasil.

\section{CITAÇÃO}

LACERDA, Jamille dos Passos. Osteonecrosis of the maxilaries associated with use of bisphosphonate. Brazilian Journal of Implantology and Health Sciences, v.1, n.2, p. 18-24, 2019.

\section{ABSTRACT}

Introduction: Bisphosphonates (BF) are inhibitors of reabsorption bone and are indicated for the treatment of Osteoporosis, Bone Metastasis, Multiple Myelomas and Paget's Disease. They are pyrophosphate analogs, which have high affinity for bone tissue inhibiting the action of osteoclasts. Although it has benefits for patients with of such diseases by assisting, for example, in the pain control prolonged use may lead to osteonecrosis of the jaws.

Objectives: This article aims to review themedical literature on the use of bisphosbonates and dental surgeries.

Materials and Methods: The indexed articles google academico and PubMed were scanned and the articles with the highest impact factor were selected.

Results: We found 350 articles and selected 20 with the highest impact factor.

Conclusion: Bisphosphonates are substances that can cause oteonecrosis in patients undergoing invasive dental treatments.

\section{PALAVRAS CHAVE}

Osteonecrosis, bisphosphonate, necrosis of the jaws 


\title{
Osteonecrosis of the maxilaries associated with use of biphosphonate
}

\begin{abstract}
Introduction: Bisphosphonates (BF) are inhibitors of reabsorption bone and are indicated for the treatment of Osteoporosis, Bone Metastasis, Multiple Myelomas and Paget's Disease. They are pyrophosphate analogs, which have high affinity for bone tissue inhibiting the action of osteoclasts. Although it has benefits for patients with of such diseases by assisting, for example, in the pain control prolonged use may lead to osteonecrosis of the jaws.

Objectives: This article aims to review themedical literature on the use of bisphosbonates and dental surgeries.

Materials and Methods: The indexed articles google acadêmico and PubMed were scanned and the articles with the highest impact factor were selected.

Results: We found 350 articles and selected 20 with the highest impact factor.

Conclusion: Bisphosphonates are substances that can cause oteonecrosis in patients undergoing invasive dental treatments.
\end{abstract}

Key words: Osteonecrosis, bisphosphonate, necrosis of the jaws 
Osteonecrosis of the maxilaries associated with use of bisphosphonate

Jamille dos Passos Lacerda

\section{INTRODUCTION}

Bisphosphonates in the 1960s were presented as a therapeutic drug for diseases with impaired bone, but are currently prescribed primarily for the treatment of osteoporosis 3 .

This medicine has the ability to bind to bone and inhibit the function of osteoclasts because they are analogous of pyrosphosphates. Not being metabolized by the organism the concentration at the bone level and for months / years. Such drugs decrease bone turnover which inhibit bone resorption at tissue level. In the cells the bisphosphonates have action on the osteoclástos, It may be through inhibition of recruitment of osteoclasts, by inhibiting the lifespan of the osteoclasts and their activity on the bone surface. In relation to the molecules, they bind to the receptor of surface of the osteoclasts or in an intracellular enzyme 3.

They can be found in two presentations, for orally indicated for the treatment of Osteoporosis, Osteopenia and Paget's disease and endovenous route used in Oncological diseases. Adverse reactions are: asthenia, anemia, dyspnoea, changes in creatinine levels, gastrointestinal symptoms and esophageal ulcers 13.

He reports that treatment consists of eliminating pain and prevent recurrence of infections and symptoms, through of antibiotic therapy, when signs of infection are gifts, and topical antimicrobial agents. Exist situations in which the associated hyperbaric therapy the surgery and the interruption or substitution of the administration of the drug for six months, being three before and three months after the procedure are indicated 2.

The objective of this study is to report the possible complications that can occur in a procedure in patients taking bisphosphonates on a long-term basis.

\section{METHODS}

To perform a literature review on case reports that refer to the etiology, characteristics and therapeutics of osteonecrosis associated with the use of bisphosphonate in database of Bireme, Scielo and Google Scholar.

Articles, dissertations and theses were searched in Portuguese, English and Spanish indexed in computerized archives of the bases cited above.

\section{SYSTEMATIC REVIEW}

Bisphosphonates prevent cell characterization osteoclast percussive cells its action, inciting the cellular apoptosis, altering the cellular structure in the period that precedes this fact. There is a of cytoplasmic prominences responsible for the 
Osteonecrosis of the maxilaries associated with use of bisphosphonate

Jamille dos Passos Lacerda

deterioration of the organic matrix of tissue bone. In addition to such activities, antiangiogenic properties such as decreased number of blood vessels and endothelial responses to angiogenic hormones have been described 1.

Treatment consists of eliminating pain complaints and prevent recurrence of infections and symptoms, through of antibiotic therapy, when signs of infection are gifts, and topical antimicrobial agents. Exist situations in which the associated hyperbaric therapy the surgery and the interruption or substitution of the administration of the drug for six months, being three before and three months after the procedure are indicated 2.

The AOMS ranked in three the stages for the OMAB, first stage: bone necrosis with exposure without evidence of infection and symptoms, according to stage: necrosis with bone exposure, infection (pain, erythema with or without purulent drainage), third stage: bone necrosis with bone exposure, infection and possible pathological fractures, extra oral fistulas, osteolysis involving lower lip of the mandible. The treatment consists in the use of mouthwashes in the three stages, Antibiotic therapy accompanied by microbiological and analgesic culture for pain relief and debridement (second and third stages), third stage the debridement becomes more aggressive 3 .

In 2009, the AOMS classified the risk factors for ONMS, first category: drugrelated factors (potency and duration of second category: demographic and systemic risk factors (the Caucasian race has a greater predisposition about $9 \%$ per decade), third category: rich local factors (dentoalveolar surgery, local anatomy and concomitant oral diseases) fourth category: genetic risk factors and fifth category: factors preventive measures (evaluation of the oral health status before onset of therapy 4 .

The components of such drugs are stored in the bone matrix and can remain for years in the organism, resulting in the degeneration of capillaries, vascularization and are susceptible to fracture 5 .

The first publication of a case report on osteonecrosis in the mandible occurred in 2003 reported Max. The bone necrosis is irreversible, since the tissue bone and unable to undergo remodeling and for this reason he suffers necrosis 6.

Bisphosphonates are drugs indicated for the treatment of Osteoporosis, Bone Metastasis, Multiple Myelomas, Pagets Disease. The action of this drug results in increased bone mass and mineralization. Surgeries oral implants, dental implants, periodontal surgeries and maladaptive prostheses are risk factors 7 .

The absorption of the bisphosphonates is well $50 \%$ absorbed by the bone and the route of elimination are the kidneys. The Unified Health System (SUS) provides the bisphosphonates for treatment of Imperfect Osteogenesis obtaining favorable results regarding the reduction of bone fracture. Recently the Pamidronato was introduced in Fibrous Dysplasia not have a formalized protocol 8. 
Osteonecrosis of the maxilaries associated with use of bisphosphonate Jamille dos Passos Lacerda

These drugs may have side effects and result in osteonecrosis of the jaws being that for this has to have a relationship between type $\mathrm{x}$ dose $\mathrm{x}$ history of trauma $\mathrm{x}$ oral surgeries $\mathrm{x}$ infections 9 .

The efficacy of these drugs in relation to pain control (patients with clinical breast, prostate and lung and multiple myeloma0 and loss (osteonecrosis) has been proven through The jaws are more susceptible and osteonecrosis due to its location, the oral cavity, by the microbiota present 10 .

These drugs are synthetic analogous to pyrophosphate the duration of this medicinal product in the blood can be from thirty minutes to two hours but when incorporated into the bone it can remain for until a decade 11,16 .

The diagnosis is made according to the history and clinical examination of the patient. The clinical characteristics are/ the necrotic lesions that may not present symptoms for years, becoming symptomatic only When adjacent tissues present infection or inflammation, the with the CTX exam 12,17.

Bisphosphonates have benefits when prescribed for cancer treatment because it reduces bone pain and skeletal complications, AAOMS (AAmerican Association of Oral Maxillofacial Surgeons), osteonecrosis as bone tissue exposed in the maxillofacial region that remains for more than eight weeks, in patients with previous or current treatment with bisphosphonates, who do not present history and radiotherapy of head and neck 13,18 .

These medications are indicated to maintain the bone density in patients with neoplasms with bone involvement. Can some adverse effects such as fever, renal hypercalcemia, maxillary necrosis 14,19 .

The pathogenesis is still unknown and the most Acceptance is direct action on osteoclasts leading to reduction of bone remodeling and inhibition of the vascular endothelial growth. The clinical and varied aspect may present exposure of the necrotic bone with pain and radiographically diffuse bone sclerosis, presence of bone sequestration, mandibular oral fistula, diffuse radiolucent spot, in panoramic lesions osteolytic cells in vertical cortical wrapping, histologically show necrotic trabecular bone with surrounding vascular tissue covered by granulation tissue, positive culture examination for some species fungal infections other than Actyomyces Spe Streptococcus intermedia 15,20.

\section{CONCLUSION}

Further research must be carried out for a better understanding of the mechanism of action of bisphosphonates in the jaws with the purpose of proposing protocol for proper treatment and implantation of a dental protocol prior to therapy, since the tooth extractions, which is a risk factor for osteonecrosis, are common surgical procedures in underdeveloped countries with Brazil. Prevention of Osteonecrosis is still the best way to conduct this complication. The dentist surgeon should keep in touch with the patient's physician and inform the 
Osteonecrosis of the maxilaries associated with use of bisphosphonate Jamille dos Passos Lacerda

importance of maintaining oral health as a means of preventing and reduce the risks of the disease.

\section{CONFLICT OF INTEREST}

The author declares there are no conflicts of interest

\section{REFERENCES}

1- Souza FRN, Junior EGJ. Osteonecrose associada com o uso dos bifosfonato. Pesq. Bras. Odontoped. Clin. Integr. João Pessoa 2008; 8(3):375-80

2- Éber Coelho Paraguassu et al. Association of Bacterial Endocarditis and Buccomaxillofacial Surgery: Review of Current Medical Literature. OHDM-Oral Health and Dental Management, Vol. 18- No.3-June, 2019

3- Pereira FA, et al. Osteonecrose dos maxilares associada ao uso dos bifosfonatos. Rev. Bras.Cir. Cabeça e pescoço. 2009; 38(4): 283-86.

4- Lopes I, Zenhar H, Costa H, Barroso J. Osteonecrose de mandíbula associada ao uso de bifosfonato uma patologia secundaria. Arquimed. 2009; 23(5).

5- Coelho Al, Gomes OS, Fernandes MH. Osteonecrose dos maxilares associada ao uso de bifosfonato. Parte 1: Etiologia e apresentação clínica. Revista Portuguesa de Estomatologia, Medicina dentaria e Cirurgia Maxilofacial. 2010; 51(2).

6- Éber Coelho Paraguassu, Anneli Celis Mercedes de Cardenas, Marina Nolli Bittencourt, Ana Rita Pinheiro Barcessat and Paulo Fabricio Ramos. "Quality of life and satisfaction of users of total tissue-supported and implant-supported prostheses in the municipality of macapá, Brazil", International Journal of Development Research, 09, (02), 26007-26011, 2019

7- Scarpa LC, Leite LCM, Lacerda JCT, Arantes DCB. Osteonecrose nos ossos da maxila e mandíbula associada ao uso de bifosfonato sódico. Revista Brasileira de Pes- quisa em Saude. 2010; 12(1):86-92

8- Ribeiro et al. Osteonecrose dos maxilares relacionada ao uso de bifosfonatos orais: relato de caso. Rev Odontol. UNESP, Araraquara. 2011; 40(5):246-67

9- Passeri A.; Bértolo M.B e Abaubara A. Osteonecrose dos maxilares associados ao uso dos bifosfonatos. Rev Bras de Reumatologia. São Paulo. 2011; 51(4):401-7. 
10- Teixeira NNS, Moreira G. Osteonecrose associada aos bifosfonatos na odontologia- revisão de literatura. Revista Brasileira Cabeça Pescoço. 2011; 40(4):214-17.

11- Ricco AA, Vezola NHA, Orrico SRP, Giro G. Osteone- crose dos maxilares associada ao uso de bifosfonatos: relato de caso clinico. Rev Odontol. UNESP, Araraquara. 2011; 40(esp):10.

12- PARAGUASSU, Éber Coelho et al. Qualidade de vida e satisfação em usuários de prótese total no estado do Amapá, Brasil. Revista Eletrônica Acervo Saúde, n. 27, p. e876-e876, 2019

13- Dotto ML, Dotto AC. Osteonecrose dos maxilares indu- zida por bifosfonatorevisão e literatura e relato de caso. RFO, Passo Fundo. 2011; 16(2):229-33.

14- Nobre $D$ et al. Patogênese da osteonerose dos ossos ma- xilares induzida por bifosfonato: o que se sabe atualmente? RBM Rev Bras Medicina. 2012; $69(11)$.

15- Brozoski MA, et al. Osteonecrose maxilar associada ao uso de bifosfonato. Revista Brasileira Reumatol. 2012; 52(2):260-70.

16- PARAGUASSU, Éber Coelho; DE CARDENAS, Anneli Mercedes Celis. Sociodemographic characterization of users of total tissue-supported and implant-supported prostheses in the municipality of macapá, Brazil. International Journal of Development Research, v. 9, n. 02, p. 26081-26084, 2019.

17- Milani CM, Lobo M, Carilho E, Souza JÁ, Machado MA. Osteonecrose mandibular associada ao uso de bifosfonato: relato de caso. Odonto. 2012; 20(39):27-33.

18- Scansseti M, Soares L, Silva DG,Tinoco EMB,Falabela ME. Osteonecrose medicamentosa associada ao uso de bifosfonato. Perio News. 2013; 3:17682.

19- Mourão CFA, Moura AP, Manso JEF. Tratamento da osteonecrose dos maxilares associada ao bifosfonato: re- visão de literatura. Revista Bras. Cir. Cabeça Pescoço. 2013; 42(2):113-7.

20- PARAGUASSU, Eber Coelho et al. Systematic review of the epidemiology of oral cancer in Brazil. International Journal of Innovation Education and Research, v. 7, n. 4, p. 366-374, 2019. 